\title{
Plants used by Megachile (Moureapis) sp. (Hymenoptera: Megachilidae) in the provisioning of their nests
}

\author{
Buschini, MLT.*, Rigon, J. and Cordeiro, J. \\ Departamento de Biologia, Universidade Estadual do Centro-Oeste - UNICENTRO, \\ Rua Presidente Zacarias, 875, CEP 85010-990, Guarapuava, PR, Brazil \\ *e-mail: isatunes@yahoo.com.br \\ Received August 28, 2008 - Accepted October 29, 2008 - Distributed November 30, 2009
}

(With 3 figures)

\begin{abstract}
This study was carried out in the Parque Municipal das Araucárias, located in the municipality of Guarapuava (PR) from May (06) to April (07). Its aim was to investigate which plants are used by Megachile (Moureapis) sp in provisioning of larvae, and to verify if this bee is oligolectic or polilectic. The collection of the plants was carried out during the bees activity period and in an area covering a $500 \mathrm{~m}$ radius from where the nests had been built. A sample of pollens from founded nests and from flowers was used to make permanent slides using the acetolysis method and with the aid of a light microscope, all pollen grains were examined in order to identify the plants used by this bee. A total of 80 pollen grain slides, from 16 nests were analysed. Although 99 plants were collected close to the bee's nesting site, in nest slides, the pollen of Ludwigia peruviana (36\%) and Ludwigia sericea (63.6\%) (Onagraceae) accounted for $99.6 \%$ of the total amount of pollen collected. With these results we are able to conclude that Megachile (Moureapis) sp is an oligolectic species and that these plants species are their important pollen source.
\end{abstract}

Keywords: Ludwigia peruviana, Ludwigia sericea, Megachile (Moureapis) sp., provisioning.

\section{Plantas usadas por Megachile (Moureapis) sp (Hymenoptera: Megachilidae) no aprovisionamento de seus ninhos}

\begin{abstract}
Resumo
Esse estudo foi realizado no Parque Municipal das Araucárias, Guarapuava, PR, no período de maio (06) a abril (07). Seu objetivo foi investigar as plantas utilizadas por Megachile (Moureapis) sp. no aprovisionamento larval, e se essa é uma espécie oligolética ou polilética. No período de atividade destas abelhas foram realizadas coletas das plantas floridas num raio de $500 \mathrm{~m}$ dos locais onde elas estavam nidificando. Foram preparadas amostras do material polínico dos ninhos e das plantas pelo método de acetólise e com a ajuda de microscopia de luz, identificados os tipos de pólen. Foi analisado o pólen de 16 ninhos, totalizando 80 lâminas. Embora 99 plantas tenham sido coletadas próximo aos locais de nidificação desta abelha, nas lâminas provenientes dos ninhos os pólens de Ludwigia peruviana (36\%) e Ludwigia sericea (63,6\%) (Onagraceae) corresponderaram a 99,6\% dos daqueles coletados. Através desses resultados nos concluímos que Megachile (Moureapis) sp. é uma espécie oligolética e que essas plantas são suas importantes fontes de pólen.
\end{abstract}

Palavras-chave: aprovisionamento, Ludwigia peruviana, Ludwigia sericea, Megachile (Moureapis) sp.

\section{Introduction}

It is estimated that there are today, approximately four thousand amply distributed bee genera (Michener, 2000), with over twenty thousand described species (Alves-dos-Santos, 2002). Of these, more than $80 \%$ are solitary, $15 \%$ infest other species' nests and 5\% exhibit some degree of sociality (Campos et al., 1987).

The factors that explain or alter the distribution of Apoidea are probably related to the local flora abundance and diversity (Silveira et al., 2002), as well as to the oc- currence of appropriate nesting sites (Linsley, 1958). As opposed to that which has been observed for social bees, the diversity and abundance of solitary bees increases from the Equator towards the north and south poles. In South America, bee diversity is richer from the "cerrado" (Brazilian savannah) towards the southern native fields of Brazil (Michener, 1979).

Bees of the family Megachilidae are well represented in low altitude areas in southern Brazil and poorly 
abundant in the northeast (Viana and Alves-dos-Santos, 2002). The genus Megachile Latrulle, 1802 is very rich in number of species worldwide, with 524 of these recorded from the Americas (Raw, 2004). The subgenus Moureapis Raw, 2002 is most diverse in Argentina and southern Brazil, even though its distribution range reaches Mexico (Silveira et al., 2002).

Among pollinating agents, bees are the most important (Raven et al., 2001), since many flowering plants depend exclusively on them for crossed pollination to occur. In order to promote pollination, these plants have attractive features such as color, fragrances, nectar, oils and pollen which are the main resources used by bees (Raven et al., 2001; Morgado et al., 2002; Santana et al., 2002).

According to their feeding habits, bees are classified into polylectic, when they collect pollen from several species of plants, and oligolectic, when they exhibit floral fidelity, collecting pollen from few species of plants, usually belonging to a same genus or family. The oligolectic habit is usually associated to plants that occur in open areas (Schlindwein, 2000). This is due to the fact that many plants that occur in these areas have significantly large pollen grains, such as those of the genera Ludwigia L. 1753, Pavonia Cav. 1786, Sida L. 1753, Opuntia Mill. 1754 and Ipomoea L. 1753. This requires a specialised scopa with long and unbranched hairs, enabling an adequate handling of the pollen (Gimenes, 1991). Oligolectic relationships between plants and bees were demonstrated in Brazil for 19 families of plants of which Onagraceae was the one that presented the highest number of associated oligolectic bees (Schlindwein, 2004).

Generally, bees of the family Megachilidae are oligolectic (Villanueva-Gutiérrez and Roubik, 2004) playing an important role in the maintenance of plant species and being irreplaceable by generalist bees (Schlindwein, 2004). Within Megachilini, Megachile apicipennis Schrottky, 1902 shows an exclusive floral preference for plants of the genera Senecio L. 1753 and Vernonia Schreb. 1791 (Asteraceae), Megachile brasiliensis Dalla Torre, 1896 for Ludwigia (Onagraceae) and Megachile nigropilosa Schrottky, 1902 for Asteraceae such as Elephantopus L. 1753 and Vernonia (Schlindwein, 2004). Other Megachilidae bees that also show floral specificity are Liturge huberi Ducke, an Ipomoea asarifolia (Dres.) Roem. and Schult. 1819 (Convolvulaceae) pollinator (Kiill and Ranga, 2003), and Pseudocentron sp., a Sophora tomentosa L. 1753 (Fabaceae) pollinator (Nogueira and Vaz-de-Arruda, 2006).

The aim of this study was to investigate which plants are used by Megachile (Moureapis) sp. in provisioning of larvae, and to verify if this bee is oligolectic or polilectic.

\section{Material and Methods}

This study was carried out in the Parque Municipal das Araucárias, located in the municipality of Guarapuava,

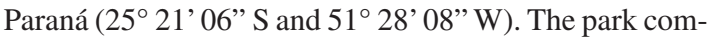

prises an area of approximately 104 ha. The vegetation is composed of Mixed Ombrophilous Forest (42.75\%), gallery forest $(10.09 \%)$, fields $(6.8 \%)$, swamps $(7.13 \%)$ and altered areas (33.23\%). According to Köoper's classification the climate is humid mesothermic with no dry season and mild summers due to the altitude. The winter is moderate with frequent occurrence of frost. Annual mean temperature stays around 16 to $17.5^{\circ} \mathrm{C}$. Average monthly rainfall is above $100 \mathrm{~mm}$ and annual $1,961 \mathrm{~mm}$, being uniform throughout the year.

For this study, data of nests collected in previous years was used (Buschini, 2006). A sample of the founded nests was used to remove pollinic material and make permanent slides, using the acetolysis method (Miranda and Andrade, 1990). For each nest five pollen grain slides were made. According to the data collected between 2001 and 2003, Megachile (Moureapis) sp. founded their nests only in swamp and field habitats. Thus, the collection of the plants was carried out only in these areas between May/06 and April/07, covering a $500 \mathrm{~m}$ radius from where the nests had been built. Pollen was removed from flowers and/or buttons of each plant in order to mount two slides per plant. With the aid of a light microscope all pollen grain slides from both nests and plants were examined in order to identify the plants used by this bee. For pollen quantification, consecutive counting of 200 pollen grains per slide was carried out, totaling 1,000 pollen grain per nest.

\section{Results}

A total of 80 pollen grain slides, from 16 nests of Megachile (Moureapis) sp. were analysed, corresponding to $53 \%$ of the number of founded nests. Of these, 13 were collected in the swamp and 3 in the field. Although 99 flowering plants were collected close to the bee's nesting site (Table 1), in nest slides, the pollen of Ludwigia peruviana (L.) H. Hara, 1953 (36\%) and Ludwigia

Table 1. Plants collected in an area covering a 500 m radius from where the Megachile (Moureapis) sp nests had been built.

\begin{tabular}{l} 
Family Species \\
\hline ACANTHACEAE \\
Ruellia brevicaulis (Ness) Lindau \\
AMARANTHACEAE \\
Gomphrena elegans Mart. \\
Pfaffia tuberosa (Sprengel) Hicken \\
ANACARDIACEAE \\
APIACEAE johnstonii $\mathrm{F}$. A. Barkley \\
Eryngium horridum Malme \\
APOCYNACEAE \\
Oxypetalum parnasum Decne. \\
ASTERACEAE
\end{tabular}


Table 1. Continued...

\begin{tabular}{|c|c|}
\hline Family & Species \\
\hline & $\begin{array}{l}\text { Austrupatorim laetevirens (Hook. and Arn.) } \\
\text { R.M King and H. Rob. }\end{array}$ \\
\hline & $\begin{array}{l}\text { Austroeupatorium picturatum (Malme). } \\
\text { R. M. King and H. Rob. }\end{array}$ \\
\hline & Baccharis anomala DC. \\
\hline & Baccharis articulata (Lam.) Pers. \\
\hline & Baccharis dracunculifolia DC. \\
\hline & Baccharis helichrysoides DC. \\
\hline & Baccharis microdonta DC. \\
\hline & Baccharis sp. \\
\hline & Baccharis uncinella DC. \\
\hline & Calea cymosa Less. \\
\hline & Calea hispida (DC) Baker. \\
\hline & $\begin{array}{l}\text { Campovassouria cruciata } \\
\text { (Vell.) R. M. King and H. Rob. }\end{array}$ \\
\hline & $\begin{array}{l}\text { Campuloclinium macrocephalum } \\
\text { (Less.) DC. }\end{array}$ \\
\hline & $\begin{array}{l}\text { Campuloclinium purpurascens } \\
\text { (Sch. Bip. ex Baker) R. M. King and } \\
\text { H. Rob }\end{array}$ \\
\hline & $\begin{array}{l}\text { Chromolaena congesta } \\
\text { (Hook. and Arn.) R. M. King and H. Rob. }\end{array}$ \\
\hline & $\begin{array}{l}\text { Chromolaena laevigata } \\
\text { (Lam.) R. M. King. and H. Rob. }\end{array}$ \\
\hline & Chromolaena stachyophylla \\
\hline & Chrysolaena platensis (Spreng.) H. Rob \\
\hline & Chrysolaena propinqua (Hieron.) H. Rob. \\
\hline & $\begin{array}{l}\text { Erechtites valerianifolius } \\
\text { (Link ex Spreng.) DC. }\end{array}$ \\
\hline & Erigeron maximus (D. Don.) Otto ex DC. \\
\hline & Eupatorium macrocephalum Less. \\
\hline & Gochnatia polymorpha (Less.) Cabrera \\
\hline & $\begin{array}{l}\text { Grazielia serrata (Spreng.) } \\
\text { R. M. King and H. Rob. }\end{array}$ \\
\hline & Lessingianthus glabratus (Less.) H. Rob. \\
\hline & $\begin{array}{l}\text { Lessigianthus plantaginodes } \\
\text { (Kuntze) H. Rob. }\end{array}$ \\
\hline & Mikania micrantha Kunth \\
\hline & Mikania pinnatiloba DC. \\
\hline & Polymnia connata (Spreng.) S. F. Blake \\
\hline & Senecio brasiliensis ( Spreng.) Less. \\
\hline & Solidago chilensis Meyen \\
\hline & Stevia tenuis Hook. and Arn. \\
\hline & $\begin{array}{l}\text { Symphyotrichum squamatum } \\
\text { (Spreng.) G. L. Nesom }\end{array}$ \\
\hline & Trixis sp. \\
\hline & Venonanthura tweedieana (Baker) H. Rob. \\
\hline & Vernonanthura westiniana (Less.) H. Rob. \\
\hline & Vittetia orbiculata (DC.) \\
\hline & R. M. King and H. Rob. \\
\hline
\end{tabular}

Table 1. Continued...

\begin{tabular}{l} 
Family \\
\hline BALSAMINACEAE \\
Impatiens sp. \\
BEGONIACEAE \\
Begonia fischeri Schrank \\
Begonia cucullata Willd. \\
BORAGINACEAE \\
Moritzia dusenii I. M. Jonst. \\
CAMPANULACEAE \\
Lobelia camporum Pohl \\
(Chocampylus verticillatus \\
G. Don \\
Lonicera japonica Thunb. \\
CAPRIFOLIACEAE \\
COMmelina erecta L.
\end{tabular}
Ipomoea grandifolia (Dammer) O' Donell. Ipomoea indivisa (Vell.) Hallier f. Ipomoea purpurea (L.) Roth. Ipomoea $\mathrm{sp}$.

\section{CURCUBITACEAE}

Sycios polyacanthus

ESCALONIACEAE

\section{EUPHORBIACEAE}

Escallonia bifida Link and Otto

\section{FABACEAE}

Desmodium incanum DC.

Eriosema crinitum (Kunth) G. Don.

Mimosa flocculosa Burkart

Mimosa lanata Benth.

Senna multijuga (Rich.)

H. S. Trwin and Barneby

Sesbania punicea (Cav.) Benth.

Trifolium riograndense Burkart

GESNERIACEAE

Sinningia allagophylla (Mart.) Wiehler

\section{HYPERICACEAE}

\section{LAMIACEAE}

Hypericum connatum Lam.

Hypericum brasiliense Choisy

Leorunus sibiricus L.

Hoehnea scutellarioides (Benth.)

Hyptis lappulacea Mart. ex Benth.

\section{LYTHRACEAE}

Cuphea glutinosa Cham. and Schltdl. Cuphea sp. 
Table 1. Continued...

\begin{tabular}{|c|c|}
\hline Family & Species \\
\hline & Heimia myrtifolia Cham. and Schltdl. \\
\hline \multicolumn{2}{|c|}{ MALPIGHIACEAE } \\
\hline & Janusia guaranitica (A. St.-Hil.) A. Juss. \\
\hline MALVAC & EAE \\
\hline \multicolumn{2}{|c|}{ Pavonia guerkeana R. E. Fr. } \\
\hline \multicolumn{2}{|r|}{ Sida rhombifolia $\mathrm{L}$. } \\
\hline \multicolumn{2}{|c|}{ Sida sp. } \\
\hline \multicolumn{2}{|c|}{ MELASTOMATACEAE } \\
\hline \multicolumn{2}{|c|}{ Tibouchina cerastifolia Cong. } \\
\hline \multicolumn{2}{|c|}{ MYRTACEAE } \\
\hline \multicolumn{2}{|r|}{$\begin{array}{l}\text { Campomanesia adamantium } \\
\text { (Cambess) O. Berg }\end{array}$} \\
\hline \multicolumn{2}{|r|}{ Eugenia speciosa Cambess. } \\
\hline \multicolumn{2}{|c|}{ ONAGRACEAE } \\
\hline \multicolumn{2}{|c|}{ Ludwigia peruviana (L.) H. Hara } \\
\hline \multicolumn{2}{|c|}{ Ludwigia sericea (Cambess.) H. Hara } \\
\hline \multicolumn{2}{|c|}{ OROBANCHACEAE } \\
\hline & Castilleja arvensis Schltdl. and Cham. \\
\hline \multicolumn{2}{|c|}{$\begin{array}{l}\text { Castilleja arvensis Schltdl. and Cham. } \\
\text { POLYGONACEAE }\end{array}$} \\
\hline \multicolumn{2}{|c|}{ Polygonum acuminatum Kunth } \\
\hline \multicolumn{2}{|c|}{ Polygonum punctatum Elliott } \\
\hline \multicolumn{2}{|c|}{ RUBIACEAE } \\
\hline \multicolumn{2}{|c|}{ Diodia brasiliensis Spreng. } \\
\hline \multicolumn{2}{|r|}{$\begin{array}{l}\text { Galianthe dichasia (Sucre and Costa) } \\
\text { E. L. Cabral }\end{array}$} \\
\hline \multicolumn{2}{|r|}{ Galianthe sp. } \\
\hline \multicolumn{2}{|c|}{ SOLANACEAE } \\
\hline \multicolumn{2}{|r|}{ Cestrum corymbosum Schldl. } \\
\hline \multicolumn{2}{|r|}{ Solanum americanum Mill. } \\
\hline \multicolumn{2}{|r|}{ Solanum sp. } \\
\hline \multicolumn{2}{|r|}{ Solanum variabile Mart. } \\
\hline \multicolumn{2}{|r|}{ Vassobia breviflora (Sendtn.) Hunz. } \\
\hline \multicolumn{2}{|c|}{ VERBENACEAE } \\
\hline \multicolumn{2}{|c|}{ Verbena hirta Spreng. } \\
\hline \multicolumn{2}{|r|}{ Verbena rigida Spreng. } \\
\hline & Verbena sp. \\
\hline STERCU & LIACEAE \\
\hline & Waltheria douradinha Saint-Hilaire \\
\hline
\end{tabular}

sericea (Cambess.) H. Hara, 1953 (63.6\%) (Onagraceae) (Figure 1) accounted for $99.6 \%$ of the total amount of pollen collected (Figure $2 \mathrm{a}$ and $\mathrm{b}$ and Figure 3 ). In these slides, the sporadic occurrence of pollen of Tibouchina cerastifolia Cogn, 1885 (Melastomataceae), Solanum L. 1753 (Solanaceae) (Figure 2d) and Asteraceae were also observed (Table 2).

Pollen morphology of Ludwigia peruviana and Ludwigia sericea is quite similar. Thus, to better distinguish the species, measurements were taken of 25 ran- domly picked pollen grains. Description followed Punt et al. (1999) and Miranda and Andrade (1990). The pollen of these plants are multiplanar grains with medium sized tetrahedral tetrads, triangular amb and oblate spheroidal shape. The mean values obtained for the pollen of Ludwigia peruviana were $46 \mu \mathrm{m}$ for the diameter $(\mathrm{DM}=2.7)$ and $2.6 \mu \mathrm{m}$ for the width of the exine, the latter with rugulate ornamentation. For Ludwigia sericea, the mean values were $34 \mu \mathrm{m}$ for the diameter $(\mathrm{DM}=2.3$ ) and $1.4 \mu \mathrm{m}$ for the width of the exine, with only slightly rugulate ornamentation (Figure 1c and d). Thus, species were separated mainly by the size of their pollen grains and by the width and ornamentation of the exine.

Both species of Ludwigia are herb-subshrub and occurred only in swamp areas. Ludwigia sericea flowered most intensively during the month of February while Ludwigia peruviana flowered most intensively in March, although their flowering periods occur during other months as well.

\section{Discussion}

Our results show that the two species of Ludwigia are basically the only source of pollen used by this bee in the provisioning of the nests. The fact that the pollen of Ludwigia sericea appeared on the slides in considerably higher quantities does not mean that there is a preference for Ludwigia sericea by Megachile (Moureapis) sp. because the analysis of each individual nest showed that Ludwigia peruviana was present in higher quantities.

The occurrence of pollen of Tibouchina cerastifolia, Solanum and Asteraceae, in small quantities, might be due to contamination by wind or by the presence of other pollinating sources in the flowers of Ludwigia due to the flux of visitors and not due to the fact that these plants are important food sources for Megachile (Moureapis) sp.

Since the flowering period of Ludwigia peruviana and Ludwigia sericea corresponded to the period of highest nesting activity of Megachile (Moureapis) sp., there seems to be a synchrony between these plants and the bees. This had already been observed by Laroca (1972), who stated that a perfect synchrony between the bee's reproductive cycle and the plant's flowering period is necessary for the bee to be considered a specialist. This situation becomes very delicate if the plant's flowering period is short and unpredictable. Robertson (1914) cited by Antonini (1995) states that, in addition to the synchrony between the plant's flowering period and the bee's reproductive activity, the effort to avoid competition, short flights and nesting in areas close to the plants used in nest provisioning are factors that lead to the evolution of oligolecty. Vieira (2002) stated that in southeastern Brazil, all Ludwigia species have flowers that are open for only one day and that the flowering period is concentrated in the beginning of the dry period, when their pollinators, oligolectic bees, are active. 

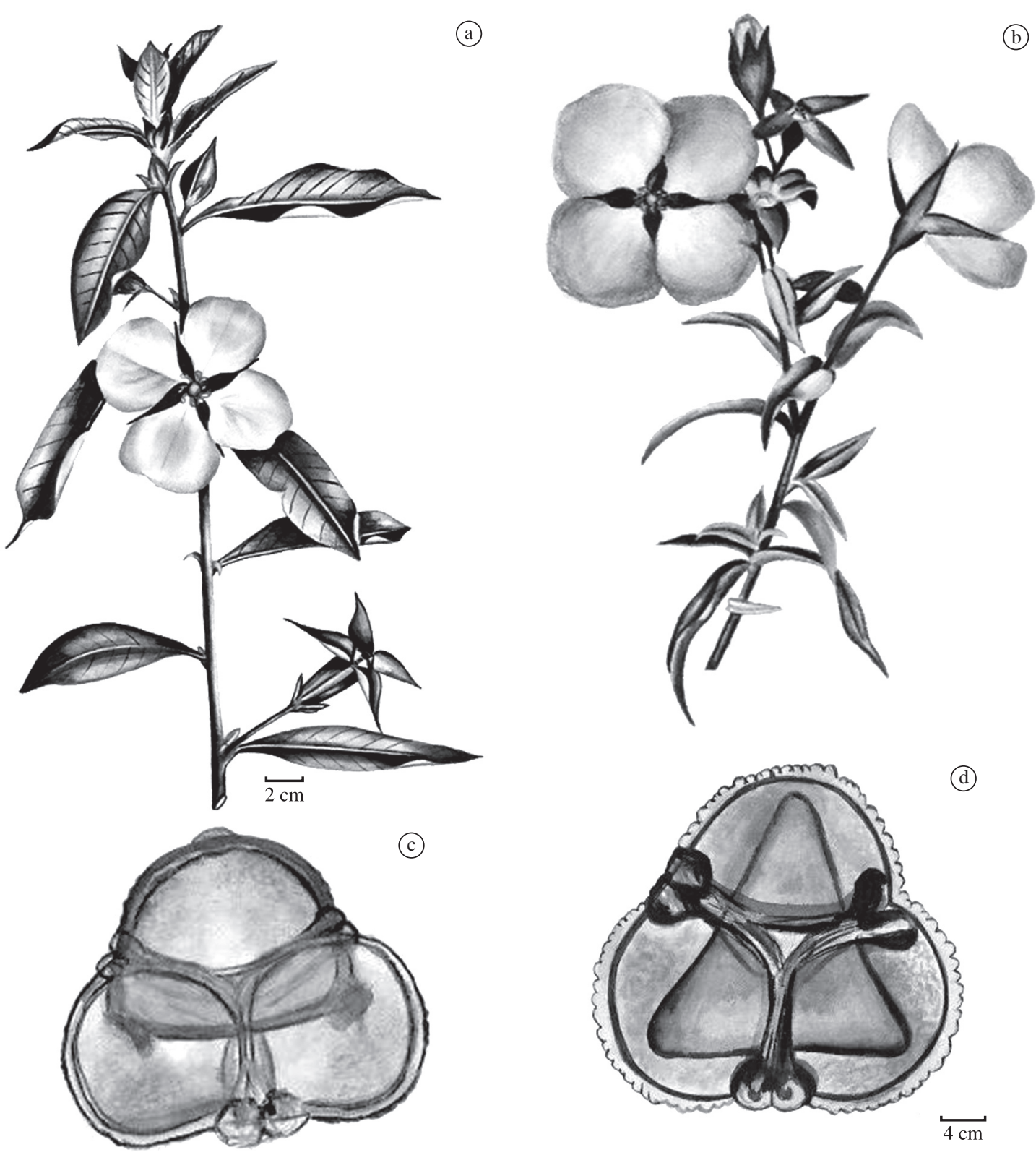

Figure 1. Species of Ludwigia in fertile stage and their pollen. a) Ludwigia peruviana, b) Ludwigia sericea, c) pollen of L. sericea e d) pollen of L. peruviana. (Illustration: Rigon, J.).

Although many species of bees can visit Ludwigia, it is probable that their pollination is carried out mostly by oligolectic bees. A study that shows this was carried out by Borges (1997) in Ludwigia laruotteana (Cambess.) H. Hara, 1953. The floral visitors of this species were Apis mellifera Linnaeus, 1758 (generalist) and Diadasina distincta (Holmberg, 1903) (specialist). According to this author, despite the aggressiveness of Apis mellifera towards Diadasina distincta, the species normally foraged at different times. Gimenes (2003) observed a high frequency of Tetraglossula anthracina (Michener, 1989), Rhophitulus sp. and Pseudagapostemon spp. in
Ludwigia elegans (Cambess) Hara, 1953 flowers. These species were considered specialists in relation to the collection of pollen and nectar in these flowers, being temporally adjusted to the flower opening schedule and with synchronised seasonality with the flowering period of this plant.

Studies have shown that the genus Ludwigia is pollinated by oligolectic bees. To date, 10 species specialised in the collection of Ludwigia pollen have been recorded, namely: Panurgillus flavitarsis Schilindwein and Moure, 1998 (Andrenidae), Diadasina distincta, Diadasina riparia (Ducke, 1913), Ptilothrix relata 
Table 2. Occurrence of pollen types in 16 nest slides of Megachile (Moureapis) sp.

\begin{tabular}{lcccccccc}
\hline \multicolumn{1}{c}{ Pollen } & I & II & III & IV & \multicolumn{1}{c}{ V } & VI & VII & VIII \\
\hline Ludwigia sericea & 864 & 677 & 690 & 508 & 986 & 446 & 943 & 690 \\
Ludwigia peruviana & 136 & 323 & 308 & 492 & 12 & 544 & 57 & 310 \\
Solanum & - & - & 2 & - & - & 10 & - & - \\
Tibouchina cerastifolia & - & - & - & - & - & - & - & - \\
Asteraceae & - & - & - & - & 2 & - & - & - \\
$\quad$ Total & 1000 & 1000 & 1000 & 1000 & 1000 & 1000 & 1000 & 1000 \\
\hline Pollen & IX & $\mathbf{X}$ & $\mathbf{X I}$ & $\mathbf{X I I}$ & $\mathbf{X I I I}$ & $\mathbf{X I V}$ & $\mathbf{X V}$ & $\mathbf{X V I}$ \\
\hline Ludwigia sericea & 948 & 476 & 871 & 506 & 363 & 17 & 992 & 213 \\
Ludwigia peruviana & 50 & 522 & 119 & 486 & 635 & 983 & 8 & 772 \\
Solanum & 1 & - & 9 & 4 & 1 & - & - & 3 \\
Tibouchina cerastifolia & - & - & - & - & - & - & - & 10 \\
Asteraceae & 1 & 2 & 1 & 4 & 1 & - & - & 2 \\
$\quad$ Total & 1000 & 1000 & 1000 & 1000 & 1000 & 1000 & 1000 & 1000 \\
\hline
\end{tabular}
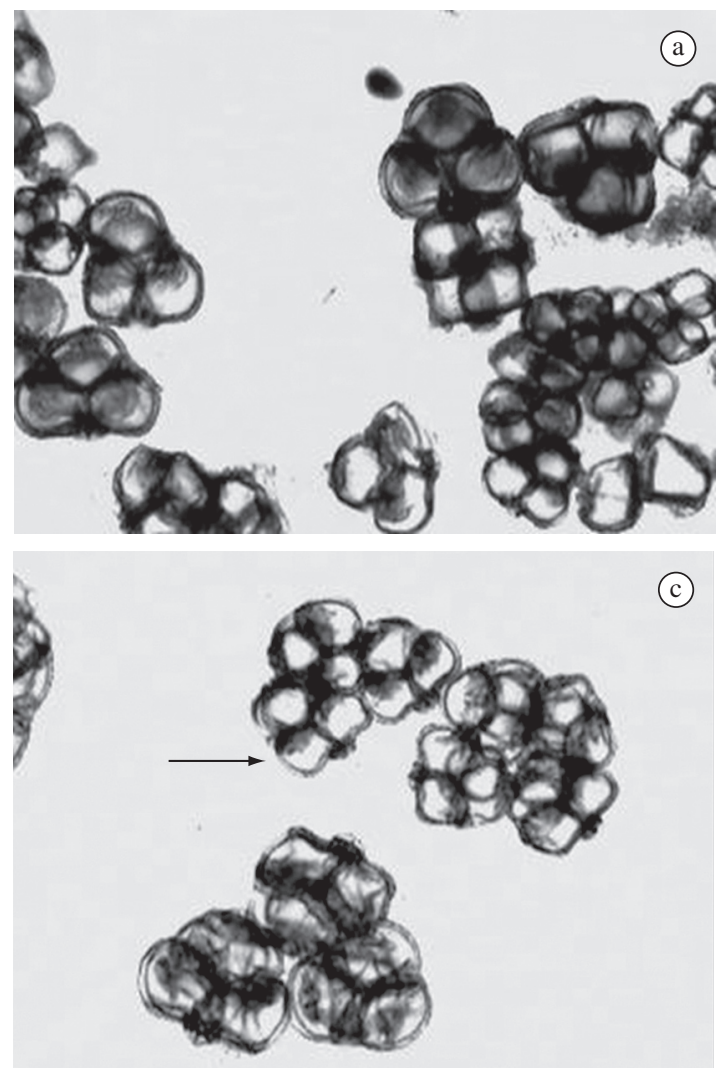

(c)
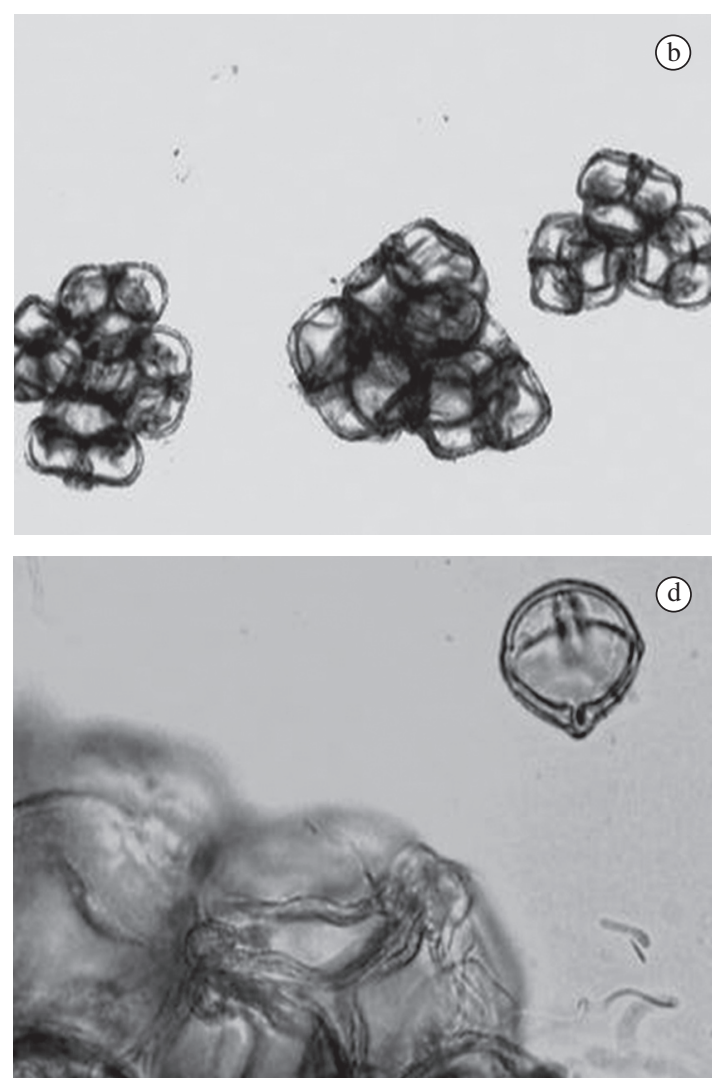

Figure 2. Pollen grains of Megachile (Moureapis) sp. a, b and c) nests, pollen of Ludwigia sericea (smaller grains, arrow) and of Ludwigia peruviana (larger grains) magnification 100×. d) Pollen of Solanum (upper right side), this type showed sporadic occurrence, magnification $400 \times$.

(Holmberg, 1903), Melissoptila paraguayensis (Brèthes, 1909) (Apidae), Tetraglossula anthracina, Tetraglossula bigamica (Strand, 1910) (Colletidae) Pseudagapostemon brasiliensis Cure, 1989, Pseudagapostemon pruinosus
Moure and Sakagami, 1984 (Halictidae) and Megachile brasiliensis (Megachilidae) (Schlindwein, 2004). Thus, Megachile (Moureapis) sp. is one more oligolectic species to be included in this list. 


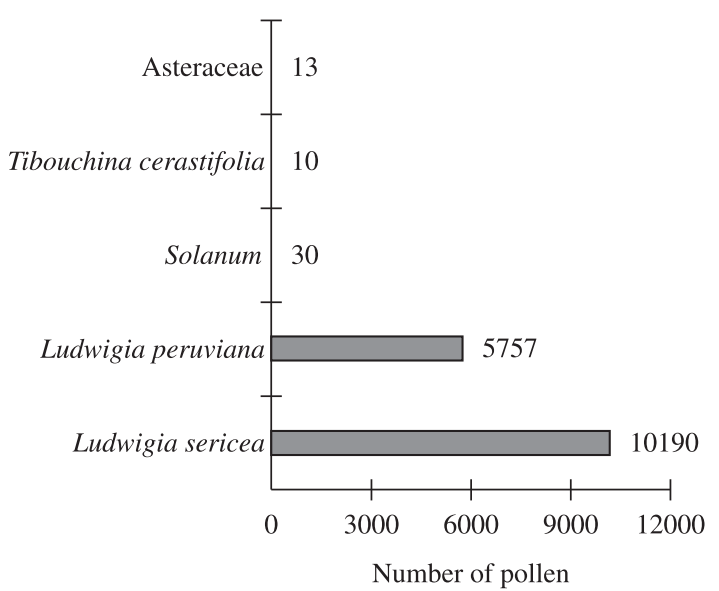

Figure 3. Number of types of pollen per botanical species found in nests of Megachile (Moureapis) sp.

According to Odum (1988), specialisation arises if this characteristic holds some kind of competitive advantage for the species. In general, oligolectic bees show morphological and/or behavioural adaptations that make them better collectors than generalist species (Schlindwein and Martins, 2000; Schlindwein, 2004; Pinheiro and Schlindwein, 1998). In Megachile (Moureapis) sp. the ventral scopa used as a pollen collecting structure, is a morphological trait that probably enables these bees to collect pollen from Ludwigia flowers very efficiently. Raven (1979) points out that bees with rigid and sparse ventral bristles are successful in the collection of Onagraceae pollen. Also, according to Borges (1997) the structural aspect of the pollen of Ludwigia facilitates collection by specialised pollinators. With these results we are able to conclude that Megachile (Moureapis) sp. is an oligolectic species and that both Ludwigia peruviana and Ludwigia sericea are their pollen source. We can also conclude that there is a synchrony between the phenology of Megachile (Moureapis) sp. and L. peruviana and L. sericea, indicating that Megachile (Moureapis) sp. is one of their main pollinators.

Acknowledegements - Partial financial support was provided by the Fundação Araucária (The State of Paraná Research Foundation) and UNICENTRO (Guarapuava -PR, Brazil). We would like to thank Vanessa Luz for her help.

\section{References}

ALVES dos SANTOS, I., 2002. A vida de uma abelha solitária. Ciência Hoje, no. 179, p. 60-62.

ANTONINI, Y., 1995. Ecologia de população de uma abelha solitária especialista Diadasina distincta (Holmberg, 1903): variação sazonal na razão sexual e no uso do pólen. Belo Horizonte: Universidade Federal de Minas Gerais. 60 p. [Dissertação de Mestrado].
BORGES, JC., 1997. Interações entre espécies de Ludwigia (Onagraceae) e seus visitantes florais. Belo Horizonte: Universidade Federal de Minas Gerais. 53 p. [Dissertação de Mestrado].

BUSCHINI, MLT., 2006. Species diversity and community structure in trap-nesting bees in Southern Brazil. Apidologie, vol. 37 , no. 37 , p. $58-66$.

CAMPOS, LAO., MORATO, E., MELO, GR. and SILVEIRA, FA., 1987. Abelhas: criação e preservação. Informe Agropecuário, vol. 13, no. 14, p. 7-14.

GIMENES, M., 2003. Interaction between visiting bees (Hymenoptera, Apoidea) and flowers de Ludwigia elegans (Camb.) Hara (Onagraceae) during the year in two different areas in São Paulo, Brazil. Revista Brasileira de Biologia = Brazilian Journal of Biology, vol. 63, no. 4, p. 617-625.

1991. Some morphological adaptations in bees (Hymenoptera, Apoidea) for collecting pollen from Ludwigia elegans (Onagraceae). Revista Brasileira de Entomologia, vol. 35 , no. 2, p. 413-422.

KIILL, LHP. and RANGA, NT., 2003. Ecologia da polinização de Ipomoea asarifolia (Ders.) Roem. and Schult. (Convolvulaceae) na região semi-árida de Pernambuco. Acta Botanica Brasilica, vol. 17 , no. 3, p. 355-362.

LAROCA, S., 1972. Estudo Feno-ecológico em Apoidea do Litoral e Primeiro Planalto Paranaense. Curitiba: Universidade Federal do Paraná. 62 p. [Dissertação de Mestrado].

LINSLEY, EG., 1958. The ecology of solitary bees. Hilgardia, vol. 27 , no. 19 , p. 543-591.

MICHENER, CD., 2000. The bees of the world. Baltimore: The Johns Hopkins University Press. 913 p.

,1979. Biogeography of the bees. Annals of the Missouri Botanical Garden, vol. 66, no. 3, p. 277-347.

MIRANDA, MMB. and ANDRADE, TAP., 1990. Fundamentos de Palinologia. Fortaleza: Imprensa Universitária. 99 p.

MORGADO, LN., CARVALHO, CF., SOUZA, B. and SANTANA, MP., 2002. Fauna de abelhas (Hymenoptera: Apoidea) nas flores de girassol Helianthus annuus L., em LavrasMG. Ciência e Agrotecnologia, vol. 26, no. 6, p. 1167-1177.

NOGUEIRA, EML. and VAZ de ARRUDA, L., 2006. Fenologia reprodutiva, polinização e sistema reprodutivo de Sophora tomentosa L. (Leguminosae-Papilionoideae) em restinga da praia da Joaquina, Florianópolis, sul do Brasil. Biotemas, vol. 19 , no. 2 , p. $29-36$.

ODUM, EP., 1988. Ecologia. Rio de Janeiro: Guanabara Koogan. 434 p.

PINHEIRO, M. and SCHLINDWEIN, C., 1998. A câmara nectarífera de Ipomoea cairica (L.) Sweet (Convolvulaceae) e abelhas de glossa longa como polinizadores eficientes. Iheringia Série Botânica, vol. 51, no 1, p. 3-16.

PUNT, W., BLACKMORE, S., NELSSON, SA. and LETHOMAS, A. 1999. Glossary of pollen and spore terminology. Netherlands: Universiteit Utrecht. Available from: $<$ http://www.biol.ruu.nl/ palaeo/glossary/glos-int.htm $>$. Access in: $08 / 08 / 2007$

RAVEN, PH., 1979. A survey of reprodutive biology in Onagraceae. Journal of Botany, vol. 17, no. 4, p. 575- 593. 
RAVEN, PH., EVERT, RF. and EICHOOORN, SE., 2001. Biologia Vegetal. 6 ed. Rio de Janeiro: Guanabara Koogan. $906 \mathrm{p}$.

RAW, A., 2004. Ambivalence over Megachile. In FREITAS, BM. and PEREIRA, JOP. (Eds). Solitary bees: conservation, rearing and management for pollination. Fortaleza: Imprensa Universitária. p. 175-184.

SANTANA, MP., CARVALHO, CF., SOUZA, B. and MORGADO, LN., 2002. Abelhas (Hymenoptera: Apoideae) visitantes das flores do feijoeiro, Phaseolus vulgaris L., em Lavras e Ijaci - MG. Ciência e Agrotecnologia, vol. 26, no. 6, p. 1119-1127.

SCHLINDWEIN, C., 2000. Importância de abelhas especializadas na polinização de plantas nativas e conservação do meio ambiente. In Anais dos 4 Encontro sobre Abelhas. Ribeirão Preto: Funpec-Editora. p. 131-141. (vol. 4).

SCHLINDWEIN, C., 2004. Are oligolectic bees always the most effective pollinators? In FREITAS, BM. and PEREIRA, JOP. (Eds.). Solitary bees: conservation, rearing and management for pollination. Fortaleza: Imprensa Universitária. p. 231-240.

2004. Abelhas solitárias e flores: especialistas são polinizadores efetivos? In Anais do 55 Congresso Nacional de
Botânica e 26 Encontro Regional de Botânicos de MG, BA e ES. Viçosa: Sociedade Botânica do Brasil. p. 1-8.

SCHLINDWEIN, C. and MARTINS, CF., 2000. Competition between the oligolectic bee Ptilothrixplumata (Anthophoridae) and the flower closing beetle Pristimerus calcaratus (Curculionidae) for floral resources of Pavonia cancellata (Malvaceae). Plant Systematics and Evolution, vol. 224, no. 3-4, p. 183-194.

SILVEIRA, FA., MELO, GAR. and ALMEIDA, EAB., 2002. Abelhas brasileiras: sistemática e identificação. Belo Horizonte. $252 \mathrm{p}$.

VIANA, BF. and ALVES dos SANTOS, I., 2002. Bee diversity of the coastal sand dunes of Brazil. In KEVAN, P. and FONSECA, VLI. (Eds). Pollinating bees: the conservation link agriculture and nature. Brasília: Barbara Bela-Editora Gráfica. p. 135-153.

VIEIRA, AOS., 2002. Biologia reprodutiva e hibridação em espécies sintópicas de Ludwigia (Onagraceae) no Sudeste do Brasil. Campinas: Universidade Estadual de Campinas. 154 p. [Tese de Doutorado].

VILLANUEVA-GUTIÉRREZ, R. and ROUBIK, DW., 2004. Pollen sources of long-tongued solitary bees (Megachilidae) in the biosphere reserve of Quintana Roo, México. In FREITAS, BM. and PEREIRA, JOP. (Eds.). Solitary bees: conservation, rearing and management for pollination. Fortaleza: Imprensa Universitária. p. 185-190. 